ALCHEMY Jurnal Penelitian Kimia

Laman resmi: https://jurnal.uns.ac.id/alchemy

\title{
Deteksi Kurkumin dan Bisdemetoksikurkumin dengan Teknik Voltammetri Menggunakan Elektrode Boron-Doped Diamond
}

\author{
Wulan Tri Wahyuni ${ }^{a, b^{*}}$, Latifah Kosim Darusman ${ }^{\text {a,b }}$, Yuris Diksy ${ }^{a}$ \\ ${ }^{a}$ Divisi Kimia Analitik Departemen Kimia Fakultas MIPA Institut Pertanian Bogor Gedung Departemen \\ Kimia Wing 2 Level 1, Jalan Tanjung No.3 Kampus IPB Dramaga, Bogor \\ ${ }^{b}$ Pusat Studi Biofarmaka Tropika, LPPM Institut Pertanian Bogor Jalan Taman Kencana No.3, Kampus IPB \\ Taman Kencana Bogor \\ * Corresponding author
}

E-mail:wulantriws@apps.ipb.ac.id

DOI: 10.20961/alchemy.14.2.19576.253-266

Received 16 March 2018, Accepted 27 May 2018, Published Online 03 September 2018

\begin{abstract}
ABSTRAK
Pada penelitian ini metode deteksi kurkumin dan bisdemetoksikurkumin dikembangkan dengan teknik voltammetri siklik menggunakan elektrode boron-doped diamond. Voltammogram siklik kurkumin dan bisdemetoksikurkumin dalam larutan elektrolit tetrabutilamonium heksafluorofosfat $\left(\mathrm{TBAPF}_{6}\right)$ asetonitril masing-masing menunjukkan 2 puncak oksidasi, yaitu pada potensial $+0,4 \mathrm{~V}$ dan $+1,9 \mathrm{~V}$ vs. $\mathrm{Ag} / \mathrm{AgCl}$ untuk kurkumin, serta $+0,6 \mathrm{~V}$ dan $+2,0 \mathrm{~V}$ vs. $\mathrm{Ag} / \mathrm{AgCl}$ untuk bisdemetoksikurkumin. Hubungan linear diperoleh antara konsentrasi kurkumin maupun bisdemetoksikurkumin dengan arus puncak oksidasinya. Hubungan linear yang diperoleh adalah $I(\mu \mathrm{A})=8619,9 \mathrm{C}(\mathrm{M})+0,7285\left(R^{2}=0,9995\right)$ dan $I(\mu \mathrm{A})$ $=14658 \mathrm{C}(\mathrm{M})+16,388\left(R^{2}=0,9299\right)$ berturut-turut untuk kurkumin puncak pertama dan kedua, serta $I(\mu \mathrm{A})=$ $7953,2 \mathrm{C}(\mathrm{M})+5,3977\left(R^{2}=0,9871\right)$ dan $I(\mu \mathrm{A})=5807,7 \mathrm{C}(\mathrm{M})+7,7616\left(R^{2}=0,9981\right)$ untuk bisdemetoksikurkumin puncak pertama dan kedua. Aplikasi metode yang dikembangkan terhadap sampel buatan yang mengandung campuran kurkumin dan bisdemetoksikurkumin menghasilkan 3 puncak oksidasi pada potensial $+0,3 \mathrm{~V},+1,2 \mathrm{~V}$, dan $+2,0 \mathrm{~V}$ vs $\mathrm{Ag} / \mathrm{AgCl}$ mengindikasikan terjadinya tumpang tindih antara puncak kurkumin dan BDMC serta pergeseran puncak oksidasi. Nilai presisi pengukuran dengan metode yang dikembangkan ialah 15,86 dan $15,15 \%$ untuk kurkumin, serta 9,85 dan $31,47 \%$ untuk bisdemetoksikurkumin. Sementara nilai akurasi pengukuran ialah sebesar 96,69 dan 125,36\% untuk kurkumin, serta 97,95 dan 127,54\% untuk bisdemetoksikurkumin masing-masing berdasarkan puncak 1 dan 2. Hasil yang diperoleh menunjukkan performa analitik metode yang dikembangkan masih perlu ditingkatkan sebelum diaplikasikan untuk analisis kuantitatif.
\end{abstract}

Kata kunci: bisdemetoksikurkumin, boron-doped diamond, kurkumin, kurkuminoid, voltammetri siklik

\section{ABSTRACT}

Detection of Curcumin and Bisdemetoxycurcumin by Voltammetric Technique using a BoronDoped Diamond Electrode. This study develops a cyclic voltammetry method for simultaneous detection of curcuminoid by using boron-doped diamond electrode. Curcumin and bisdemethoxycurcumin (BDMC) in tetrabutylammonium hexafluorophosphate $\left(\mathrm{TBAPF}_{6}\right)$-acetonitrile as electrolyte solution showed two oxidation peaks at $+0.4 \mathrm{~V}$ and $+1.9 \mathrm{~V}$ for curcumin, while those for BDMC appeared at $+0.6 \mathrm{~V}$ and $+2.0 \mathrm{~V}$. Reduction peaks of both standards were not observed. In the optimum conditions, this method showed linear correlation between concentration of curcumin and BDMC with it's oxidation peak current. The equations of $I(\mu \mathrm{A})=8619.9(\mathrm{C})(\mathrm{M})+0.7285\left(R^{2}=0,9995\right)$ and $I(\mu \mathrm{A})=14658(\mathrm{C})(\mathrm{M})+16.388\left(R^{2}=0.9299\right)$ were 
obtained for curcumin, $I(\mu \mathrm{A})=7953.2(\mathrm{C})(\mathrm{M})+5.3977\left(R^{2}=0,9871\right)$ and $I(\mu \mathrm{A})=5807.7(\mathrm{C})(\mathrm{M})+7.7616$ $\left(R^{2}=0.9981\right)$ for BDMC. Meanwhile, the measurement of the artificial samples containing a mixture of curcumin and BDMC showed three oxidation peaks at $+0.3 \mathrm{~V},+1.2 \mathrm{~V}$, and $+2.0 \mathrm{~V}$. This result indicated an overlapping between curcumin and BDMC peaks and peak shifting. Precision of the developed method was expressed as percent RSD, giving value of 15.86 and $15.15 \%$ for curcumin, and 9.85 and $31.47 \%$ for BDMC. The accuracy was 96.69 and $125.36 \%$ for curcumin, meanwhile for BDMC was 97.95 and $127.54 \%$ for peak 1 and 2 . The result indicated that the method required further improvement before applied for quantitative analysis.

Keywords: bisdemethoxycurcumin, boron-doped diamond, curcumin, curcuminoid, cyclic voltammetry

\section{PENDAHULUAN}

Kunyit (Curcuma longa) merupakan salah satu tanaman obat yang banyak dimanfaatkan sebagai bahan baku jamu dan obat herbal lainnya. Senyawa aktif yang dilaporkan memberikan efek farmakologis pada kunyit ialah senyawa kurkuminoid (Long et al. 2014). Keberadaan gugus fenolik pada senyawa kurkuminoid tersebut (Gambar 1) dilaporkan dapat memberikan aktivitas antioksidan yang kuat, selain itu telah dilaporkan bahwa senyawa kurkuminoid juga memiliki efek antiinflamasi, antidiabetes, antikanker, antibakteri, dan berkhasiat mengobati Alzheimer (Çikrikci et al., 2008; Lawhavinit et al., 2010; Manaia et al., 2012; Mosovska et al., 2016). Kurkumonoid juga merupakan senyawa marker yang turut menentukan kualitas kunyit sebagai bahan baku obat herbal sehingga kadarnya dalam kunyit perlu ditentukan.

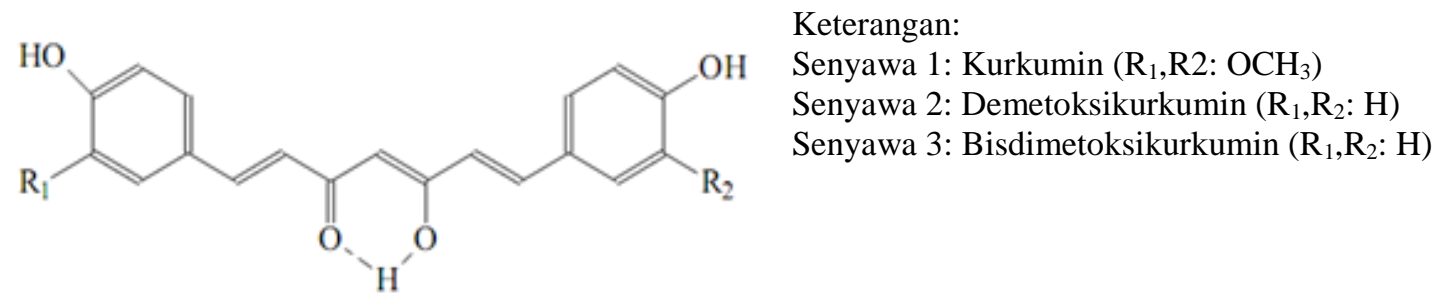

Gambar 1. Struktur kimia dari Kurkuminoid (Long et al., 2014).

Analisis kuantitatif kurkuminoid dilaporkan telah dilakukan dengan metode kromatografi lapis tipis kinerja tinggi (Nagappan et al., 2009), spektrofotometri UV-Vis (Himesh et al., 2011), metode kromatografi cair kinerja tinggi (Moorthi and Kathiresan 2013), dan ultra performance liquid chromatography (Ranjith et al., 2016). Metodemetode tersebut memerlukan pelarut dan reagen kimia beragam, membutuhkan instrumentasi tertentu, serta memerlukan waktu yang lama. Oleh karena itu diperlukan metode alternatif untuk analisis kuantitatif kurkuminoid.

Metode lain yang dapat digunakan untuk mendeteksi kurkuminoid ialah voltammetri. Metode voltammetri menawarkan beberapa keuntungan, yaitu meminimalisir 
penggunaan pelarut dan reagen kimia, menggunakan instrumentasi yang sederhana, waktu analisis yang cepat, dan teknik analisis yang mudah dan sederhana (Švorc et al., 2015). Namun demikian, analisis voltammetri untuk senyawa organik perlu dilakukan pada jendela potensial yang lebar karena puncak oksidasi dapat terjadi pada potensial yang sangat positif sementara puncak reduksinya terjadi pada potensial sangat negatif. Deteksi kurkumin telah dilakukan sebelumnya dengan menggunakan teknik voltammetri siklik menggunakan elektrode glassy carbon oleh Lungu et al. (2010) dan Long et al. (2014). Lungu et al. (2010) memperoleh tiga buah puncak oksidasi kurkumin dalam elektrolit tetraetilammonium tetrafluoroborat $0,1 \mathrm{M}$ dalam dimetilsulfoksida. Namun demikian, puncak yang muncul dari voltammogram siklik Lungu et al. (2010) belum cukup baik karena masih terdapat puncak yang berbentuk bahu dan sulit untuk diamati.

Pada penelitian ini digunakan boron-doped diamond (BDD) sebagai elektrode kerja. Diharapkan puncak oksidasi kurkuminoid yang diperoleh lebih jelas dan dapat digunakan untuk analisis kuantitatif. Elektrode BDD memiliki jendela potensial yang lebar dalam larutan encer, background current yang rendah dan stabil, sensitivitas yang rendah terhadap oksigen terlarut, memiliki konduktivitas termal yang tinggi, sangat keras, inert terhadap bahan kimia (Fujishima et al., 2005) dan secara elektrokimia stabil dalam media asam dan basa yang ekstrim (Svorc et al., 2012). Elektrode boron-doped diamond film telah berhasil digunakan dalam analisis voltammetri berbagai zat aktif biologis seperti kafein, penisilin, deteksi purin (Ivandini et al., 2007), parasetamol, kodein dan atrazin (Bandzuchova et al., 2013).

\section{METODE PENELITIAN}

Bahan-bahan yang digunakan meliputi standar kurkuminoid yang terdiri atas kurkumin dan bisdemetoksikurkumin (BDMC) diperoleh dari Tokyo Chemical Industry. Co. Ltd. (Tokyo, Jepang), reagen kimia meliputi etanol, $\mathrm{KH}_{2} \mathrm{PO}_{4}$ dan $\mathrm{K}_{2} \mathrm{HPO}_{4}$, tertabutilammonium heksafluorofosfat $\left(\mathrm{TBAPF}_{6}\right)$ diperoleh dari Sigma Aldrich (Darmstadt, Germany), dan air deionisasi. Sementara alat-alat yang digunakan meliputi elektrode kerja boron-doped diamond (diperoleh melalui sintesis dengan microwave plasma assisted chemical vapor deposition di Keio University, Jepang), elektrode platina (Pt) eDAQ ET078 sebagai elektroda lawan (counter electrode), elektrode Ag/AgCl eDAQ ET072 sebagai elektrode pembanding (reference electrode), kompartemen sel elektrokimia dengan volume $1 \mathrm{~mL}$, alat-alat kaca, mikroskop elektron payaran (SEM) JEOL JSM- 
6360LA, seperangkat alat potensiostat/galvanostat eDAQ, dan komputer yang telah dilengkapi program pengolah data Echem v.2.1.0 dan Origin Pro 8.0.

\section{Penentuan Elektrolit Pendukung}

Respon voltammetri dari larutan standar kurkumin dan bisdemetoksikurkumin (BDMC) diukur menggunakan dua jenis larutan elektrolit, yakni elektrolit berair dan elektrolit tidak berair. Pada pengukuran dengan larutan berair sebagai elektrolit, larutan standar kurkumin dan BDMC dibuat dengan konsentrasi $1 \times 10^{-4} \mathrm{M}$ dalam buffer fosfat 0,1 M pH 7. Sementara itu, pada pengukuran dengan elektrolit tidak berair larutan standar dengan konsentrasi $1 \times 10^{-4} \mathrm{M}$ disiapkan dalam larutan tetrabutilamonium heksaflorofosfat $\left(\mathrm{TBAPF}_{6}\right)$ 0,01 $\mathrm{M}$ dalam etanol dan asetonitril. Pengukuran dilakukan pada jendela potensial (-3) sampai $3 \mathrm{~V}$ vs $\mathrm{Ag} / \mathrm{AgCl}$ dengan kecepatan payar $100 \mathrm{mV} / \mathrm{s}$. Larutan elektrolit yang memberikan respon redoks yang paling baik dipilih untuk digunakan pada pengukuran selanjutnya.

\section{Evaluasi Pengaruh Kecepatan Payar}

Respon voltammetri dari larutan standar kurkumin dan BDMC 1x10-4 M dalam larutan elektrolit terpilih dievaluasi pada kecepatan payar bervariasi (50 $\mathrm{mV} / \mathrm{s}, 100 \mathrm{mV} / \mathrm{s}$, dan $200 \mathrm{mV} / \mathrm{s}$ ). Hubungan antara kecepatan payar dengan respon arus yang diperoleh selanjutnya dievaluasi.

\section{Unjuk Kerja Metode Pengukuran Kurkuminoid}

Unjuk kerja metode penentuan kurkuminoid yang dievaluasi meliputi linearitas kurva kalibrasi, presisi, dan akurasi. Penentuan linearitas dilakukan dengan menyiapkan beberapa seri larutan standar kurkumin dan BDMC dengan konsentrasi $1 \times 10^{-4} \mathrm{M}$ sampai $8 \times 10^{-3} \mathrm{M}$ dalam elektrolit terpilih. Kemudian setiap larutan diukur pada sel votammetri dengan kondisi yang telah ditentukan dan dibuat persamaan linearnya dengan metode regresi kuadrat terkecil $(y=a+b x)$. Peubah a menyatakan intersep dan $\mathrm{b}$ adalah kemiringan garis dari deret standar yang diukur. Linearitas kurva kalibrasi dilihat dari nilai koefisien determinasi $\left(R^{2}\right)$. Uji presisi dilakukan dengan mengukur standar kurkumin dan BDMC $1 \times 10^{-3} \mathrm{M}$ dalam elektrolit terpilih sebanyak 6 kali pembacaan. Presisi dinyatakan sebagai persen simpangan baku relatif (\% RSD). Akurasi dievaluasi dengan memasukkan intensitas puncak oksidasi yang diperoleh ke dalam persamaan kurva kalibrasi. Akurasi ditentukan sebanyak 3 kali ulangan. 


\section{HASIL DAN PEMBAHASAN}

Kurkuminoid merupakan senyawa diarilheptanoid yang terdiri atas 75\% kurkumin, $20 \%$ demetoksikurkumin, dan 5\% bisdemetoksikurkumin (Bansal et al., 2011). Pada penelitian ini digunakan kurkumin dan bisdemetoksikurkumin (BDMC). Struktur kurkumin dan BDMC mengandung gugus fenolik dan memiliki banyak ikatan rangkap (Gambar 1). Keberadaan gugus fungsi fenolik dan ikatan rangkap memungkinkan terjadinya reaksi oksidasi dan reduksi pada gugus tersebut. Kurkumin diketahui memiliki kemampuan untuk mendonasikan elektron (Gordon, 2014) sehingga dapat dideteksi dengan menggunakan metode elektrokimia. Namun demikian sulit untuk mengetahui puncak oksidasinya karena dapat muncul pada potensial yang sangat positif atau sangat negatif. Pada penelitian ini, deteksi kurkuminoid secara simultan dikembangkan dengan menggunakan elektrode boron-doped diamond (BDD). BDD digunakan karena mampu menampilkan puncak oksidasi maupun reduksi senyawa organik pada kisaran potensial yang lebar tanpa diganggu oleh puncak oksidasi dan reduksi pelarut.

\section{Elektrolit Pendukung}

Pemilihan elektrolit yang tepat merupakan faktor yang penting dalam analisis elektrokimia. Pada penelitian ini elektrolit pendukung yang digunakan ialah buffer fosfat $\mathrm{pH} 7$, tetrabutilammonium heksafluorofosfat $\left(\mathrm{TBAPF}_{6}\right)$ dalam etanol, dan $\mathrm{TBAPF}_{6}$ dalam asetonitril. Pengukuran terhadap standar kurkumin dan BDMC dilakukan pada rentang potensial -3 sampai 3 Volt untuk mendapatkan puncak oksidasi dan reduksi dari standar tersebut. Rentang potensial yang lebar ini digunakan karena potensial redoks senyawa organik umumnya terjadi pada daerah potensial yang lebar. Pengukuran standar kurkumin dan BDMC 1 1 10-4 M dalam 0,01 M buffer fosfat $\mathrm{pH} 7$ tidak menghasilkan puncak oksidasi maupun reduksi yang dapat didefinisikan dengan baik (Gambar 2a). Puncak oksidasi analit kurkumin dan BDMC diganggu oleh puncak oksidasi dari elektrolit. Diduga puncak oksidasi yang muncul pada elektrolit merupakan puncak oksidasi air yang merupakan pelarut dalam sistem elektrolit buffer fosfat $\mathrm{pH} 7$.

Berdasarkan hasil yang diperoleh, elektrolit berair dianggap tidak sesuai digunakan pada pengukuran kurkuminoid. Selain karena puncak oksidasi air mengganggu puncak oksidasi kurkumin dan BDMC, kelarutan kurkumin dan BDMC dalam air sangat rendah, yaitu $<0,1 \mathrm{mg} / \mathrm{mL}$. TBAPF 6 dalam pelarut etanol dan asetonitril selanjutnya dievaluasi sebagai elektrolit pengukuran kurkumin dan BDMC. Ion tetrabitilamonium $\left(\mathrm{TBA}^{+}\right)$dan heksaflorofosfat $\left(\mathrm{PF}_{6}^{-}\right)$diharapkan mampu melindungi ion-ion analit sehingga arus migrasi dapat diturunkan (Vanysek and Luis, 2008). Hasil yang diperoleh menunjukkan puncak 
oksidasi kurkumin dan BDMC sulit dibedakan dengan pelarut (Gambar 2b). Pada voltammogram siklik yang dihasilkan puncak pelarut muncul pada potensial yang sama dengan puncak analit. Diduga puncak oksidasi pelarut merupakan puncak oksidasi gugus hidroksil pada etanol. Selanjutnya dilakukan pengukuran kurkumin dan BDMC $1 \times 10^{-4} \mathrm{M}$ dalam TBAPF $_{6}$-asetonitril 0,01 M. Pada voltammogram siklik standar kurkumin dan BDMC masing-masing muncul dua puncak oksidasi yang dapat dibedakan dari voltammogram siklik elektrolit. Puncak oksidasi pada kurkumin muncul pada $+0,4 \mathrm{~V}$ dan +1,9 V vs Ag/AgCl (Gambar 2c), sedangkan pada BDMC muncul pada $+0,6 \mathrm{~V}$ dan $+2,0 \mathrm{~V}$ vs $\mathrm{Ag} / \mathrm{AgCl}$ (Gambar 2c). Pada penelitian ini tidak diperoleh puncak reduksi kurkumin maupun BDMC baik dalam pelarut air maupun pelarut organik. Hasil ini sama dengan penelitian yang telah dilakukan Ziyatdinova et al. (2012) untuk analisis kurkumin secara voltammetri siklik dalam pelarut $\mathrm{LiCl} 0,1 \mathrm{M}$ dalam etanol hanya didapatkan puncak oksidasi saja. Sementara itu, penelitian yang dilakukan Zhang et al. (2016) dan Li et al. (2014) mampu mendeteksi puncak reduksi kurkumin. Hal ini dapat terjadi karena elektrolit dan elektroda kerja yang digunakan berbeda. Zhang et al. (2016) dan Li et al. (2014) masing-masing menggunakan $10 \mathrm{mM}$ PBS pH 7.40 yang mengandung $100 \mathrm{mM} \mathrm{KCl}$ dan PBS pH 3 sebagai elektrolit. Sementara elektroda yang digunakan merupakan elektroda karbon gelas termodifikasi grafena oksida dan grafena.

Reaksi oksidasi kurkumin maupun BDMC terjadi dalam beberapa tahap sehingga puncak oksidasi yang dihasilkan lebih dari satu buah. Menurut Lungu et al. (2010) oksidasi kurkumin dalam elektrolit tetraetilammonium tetrafluoroborat $\left(\mathrm{TEABF}_{4}\right)$ pada elektroda glassy carbon menghasilkan 3 puncak oksidasi dan 2 puncak reduksi. Namun demikian puncak oksidasi yang dihasilkan oleh Lungu et al. (2010) masih sulit diamati karena berbentuk melebar dan ada yang berbentuk sebagai bahu puncak, sementara puncak reduksi yang dihasilkan sangatlah sulit diamati. Lungu et al. (2010) juga menjelaskan bahwa puncak oksidasi yang dihasilkan pada larutan elektrolit $\mathrm{pH}$ asam akan muncul 3 puncak anodik dan pada $\mathrm{pH}$ basa 2 puncak anodik.

Reaksi elektrokimia dari kurkumin secara voltammetri siklik sebenarnya dapat berupa reaksi yang reversibel, namun dalam penelitian ini hanya muncul puncak oksidasi saja. Hal ini karena ada beberapa hal yang belum terpenuhi agar reaksi oksidasi maupun reduksi kurkumin dapat terjadi saat dilakukan pengukuran secara voltammetri siklik. Long et al. (2014) menyebutkan bahwa hal-hal yang harus diperhatikan agar reaksi oksidasi dan reduksi kurkuminoid dapat teramati pada pengukuran elektrokimia antara lain efek $\mathrm{pH}$ pelarut, konsentrasi larutan elektrolit, dan juga potensial yang digunakan untuk deteksi 
kurkuminoid. Hasil dari penelitian yang diperoleh hanya didapatkan puncak oksidasi saja tidak ditemukan puncak reduksi analit. Diduga puncak reduksi analit muncul pada potensial yang sangat negatif, sehingga tidak teramati pada jendela potensial yang digunakan. Konsentrasi pelarut $\mathrm{TBAPF}_{6}$-asetonitril yang terlalu kecil juga dapat berpengaruh terhadap hasil yang diperoleh. Selain itu adanya adsorpsi pada permukaan elektroda saat dilakukan voltammetri siklik juga dapat mempengaruhi hasil analisis yang dilakukan.

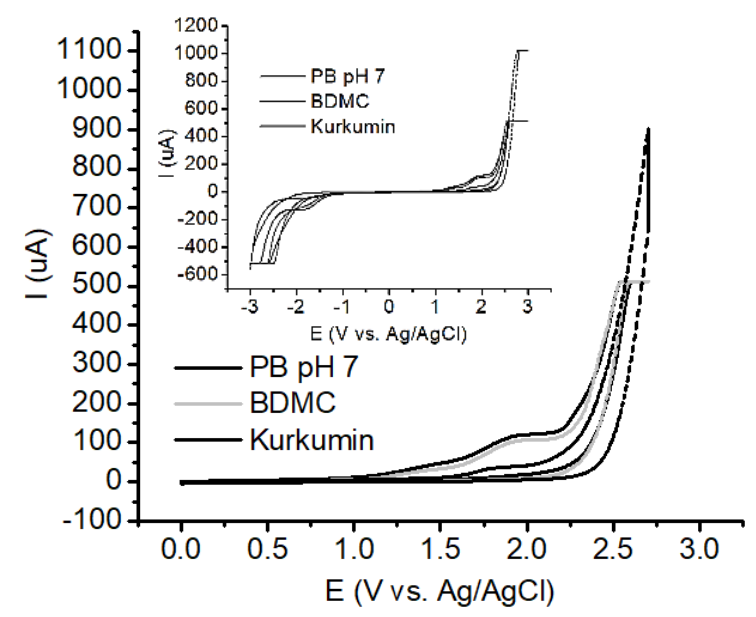

(a)

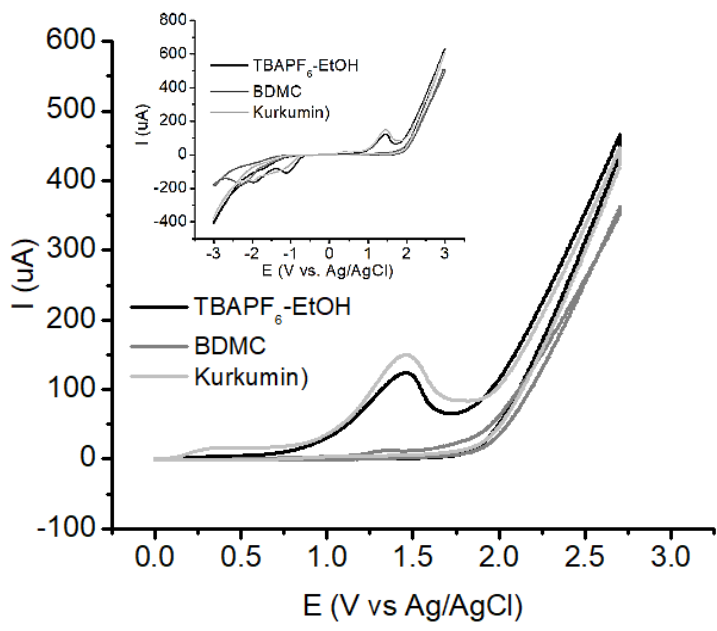

(b)

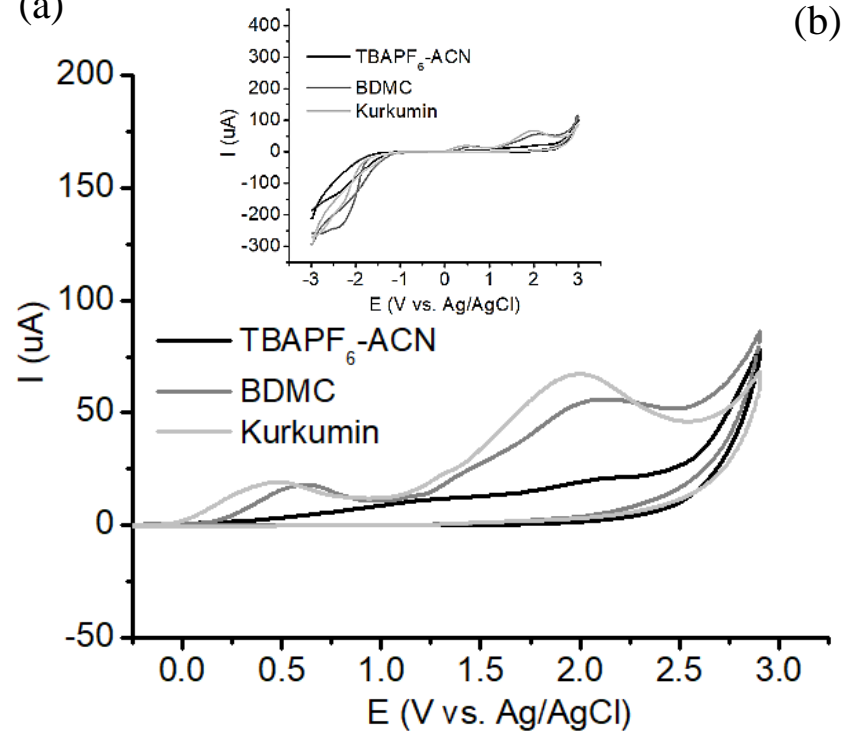

(c)

Gambar 2. Voltammogram Kurkumin dan BDMC $1 \times 10^{-4} \mathrm{M}$ dalam (a) 0,1 M buffer fosfat pH 7, (b) TBAPF6-etanol 0,01 M, (c) TBAPF6-asetonitril 0,01 M.

\section{Kecepatan Payar}

Intensitas puncak oksidasi kurkumin maupun BDMC meningkat dengan meningkatnya kecepatan payar (Gambar 3). Pada pengukuran kurkumin, hubungan kecepatan payar (v) dan intensitas arus puncak oksidasi pertama $\left(\mathrm{I}_{p a l}\right)$ memiliki koefisien 
regresi sebesar 0,9848 . Sementara untuk puncak oksidasi kedua $\left(\mathrm{I}_{p a 2}\right)$ hubungan logaritma kecepatan payar dengan logaritma arus memiliki koefisien regresi sebesar 0,9223. Pada pengukuran BDMC hubungan logaritma kecepatan payar terhadap arus puncak 1 memiliki koefisien regresi sebesar 0,9994 dan puncak 2 sebesar 0,9966. Berdasarkan hasil yang diperoleh, diduga terjadi adsorpsi spesi elektroaktif pada permukaan elektroda seperti yang dilaporkan Lungu et al. (2010). Namun demikian, transfer massa ke permukaan elektroda diduga dikontrol difusi. Menurut Wang (2006) difusi dapat terjadi dari larutan ruah ke permukaan elektroda akibat adanya gradien konsentrasi dan fluks yang meningkat pada elektroda seiring meningkatnya kecepatan payar (Wang, 2006). Semakin meningkat kecepatan payar yang digunakan maka respon arus puncak yang dihasilkan juga semakin bertambah. Pada kecepatan payar yang lebih lambat, lapisan difusi akan terbentuk lebih jauh dari elektroda dibandingkan dengan kecepatan payar yang lebih cepat. Akibatnya fluks pada permukaan elektroda jauh lebih kecil pada kecepatan payar yang lambat, dan begitu juga sebaliknya (Wang, 2006).

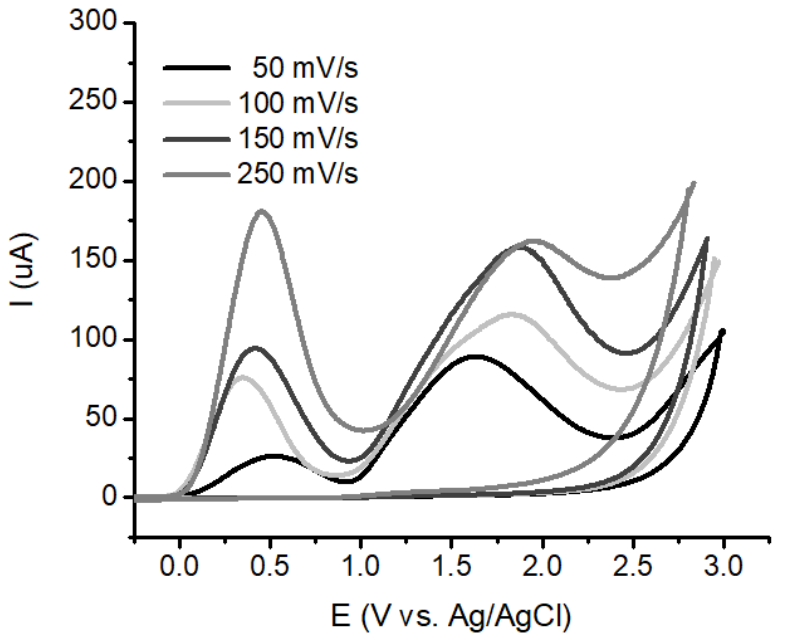

(a)

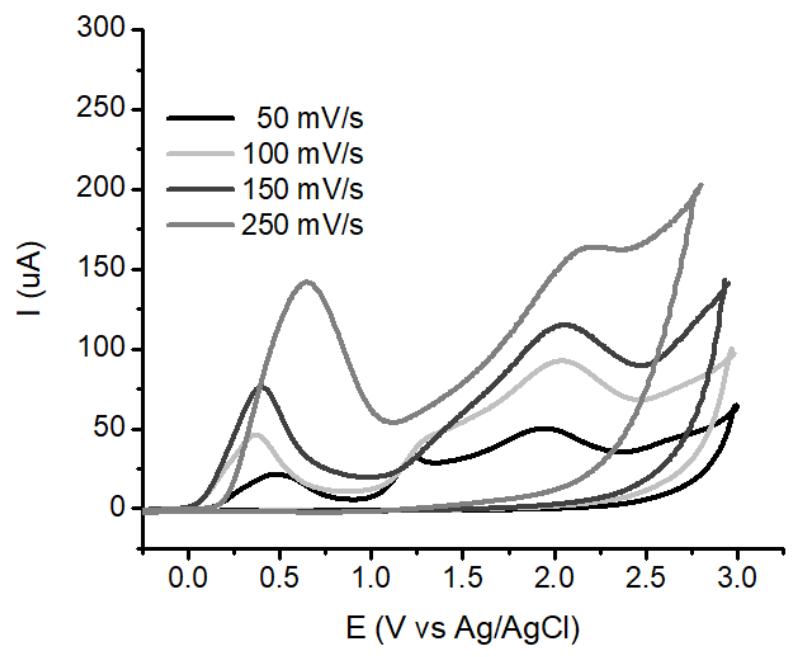

(b)

Gambar 3. Voltammogram siklik $1 \times 10^{-4} \mathrm{M}$ (a) kurkumin dan (b) BDMC dalam TBAPF $6^{-}$ asetonitril 0,01 $\mathrm{M}$ pada berbagai kecepatan payar. 


\section{Unjuk Kerja Metode Deteksi Simultan Kurkuminoid}

\section{Linearitas, Presisi, dan Akurasi Pengukuran kurkumin dan Bisdemetoksikurkumin}

Linearitas pengukuran kurkumin dan BDMC dievaluasi berdasarkan pengukuran standar kurkumin dan BDMC pada rentang konsentrasi $7 \times 10^{-4}$ hingga $5 \times 10^{-3} \mathrm{M}$. Konsentrasi terkecil dibatasi hingga $7 \times 10^{-4}$ karena pada konsentrasi lebih rendah sinyal tidak dapat dibedakan dari derau. Kurva hubungan konsentrasi dengan intensitas arus oksidasi dibuat berdasarkan puncak oksidasi 1 dan 2 masing-masing untuk kurkumin dan BDMC. Diperoleh kurva kalibrasi linear pada pengukuran kurkumin dengan nilai koefisien determinasi untuk puncak pertama adalah sebesar 0,9995 dan untuk puncak kedua sebesar 0,9299. Sementara itu, pada pengukuran BDMC diperoleh kurva kalibrasi linear dengan koefisien determinasi untuk puncak pertama sebesar 0,9871 dan puncak kedua sebesar 0,9981 (Gambar 4).

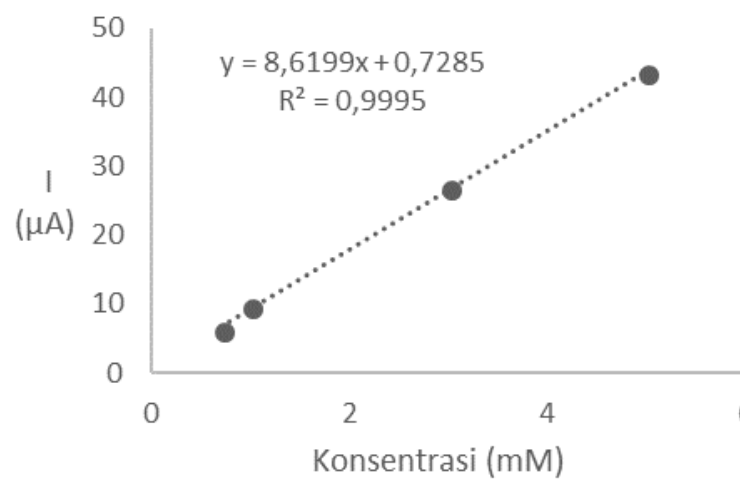

(a)

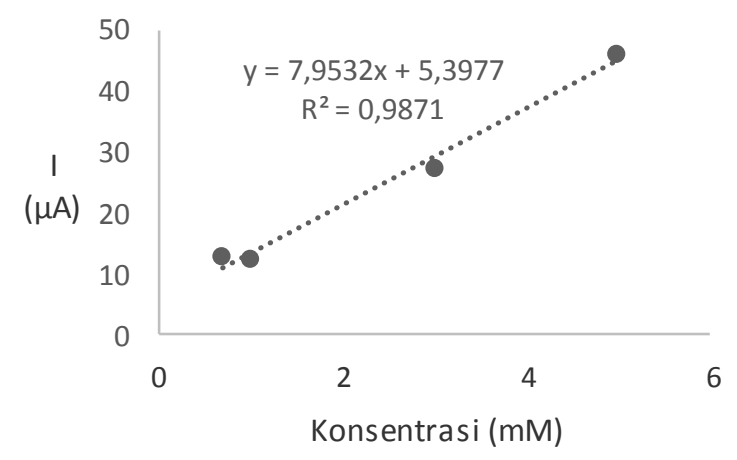

(c)

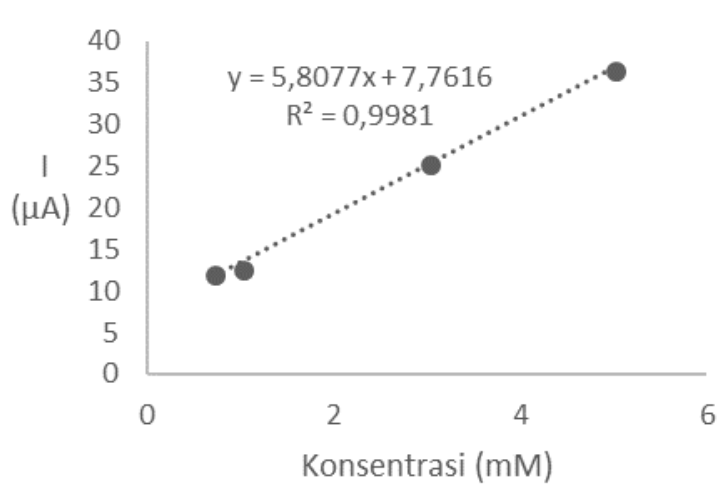

(b)

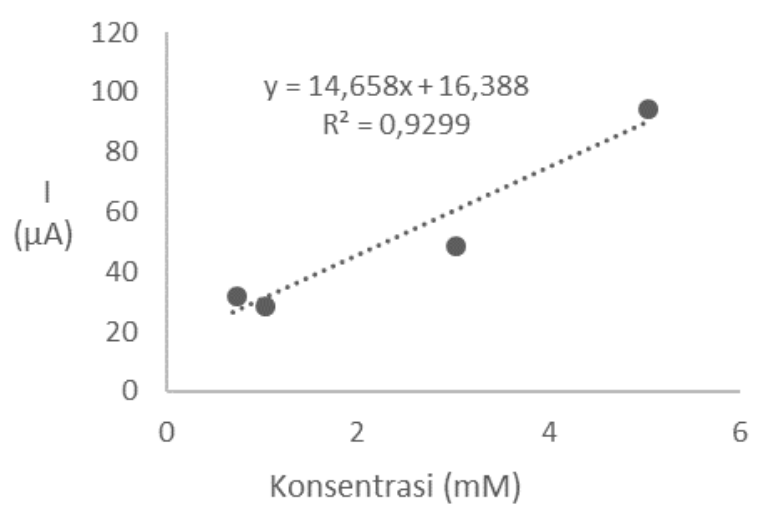

(d)

Gambar 4. Kurva kalibrasi (a) kurkumin puncak oksidasi 1, (b) kurkumin puncak oksidasi 2, (c) BDMC puncak oksidasi 1 dan (d) BDMC puncak oksidasi pada selang konsentrasi $7 \times 10^{-4}$ hingga $5 \times 10^{-3} \mathrm{M}$. 
Presisi pengukuran kurkumin dan BDMC dievaluasi berdasarkan nilai persen standar deviasi relatif (\% RSD) yang diperoleh dari pengukuran kurkumin dan BDMC sebanyak 6 kali ulangan. Syarat keberterimaan presisi didasarkan kepada nilai \% RSD yang diperoleh (Bliesner, 2006). Nilai \% RSD dihitung dari intensitas arus oksidasi, \% RSD untuk pengukuran kurkumin ialah sebesar 15,86\% (puncak oksidasi 1) dan 15,15\% (puncak oksidasi 2), sedangkan untuk BDMC sebesar 9,85\% (puncak oksidasi 1) dan $31,47 \%$ (puncak oksidasi 2). Nilai \%RSD menunjukkan pengukuran kurkumin dan BDMC kurang presisi karena nilai \% RSD di atas 5\%. Menurut AOAC metode dikatakan presisi apabila memiliki nilai \% RSD kurang dari 5\%.

Akurasi dari metode dihitung dengan membandingkan konsentrasi yang didapatkan dari pengukuran berdasarkan kurva kalibrasi linear dengan konsentrasi larutan standar yang sebenarnya digunakan (Chan et al., 2004). Dalam percobaan yang telah dilakukan, nilai akurasi dihitung dengan mengukur satu konsentrasi standar kurkumin dan BDMC sebanyak 3 kali ulangan. Akurasi pengukuran kurkumin adalah sebesar 97,69\% (puncak oksidasi 1) dan 125,36\% (puncak oksidasi 2), sedangkan untuk BDMC sebesar 97,95\% (puncak oksidasi 1) dan 127,54\% (puncak oksidasi 2). Puncak oksidasi 1 memberikan akurasi yang lebih baik dibandingkan puncak 2, baik pada pengukuran kurkumin maupun BDMC. Menurut AOAC \% akurasi yang diterima untuk konsentrasi analit 0,03\% adalah pada rentang 98-108\%. Secara keseluruhan presisi dan akurasi pengukuran kurkumin dan BDMC secara voltammetri masih perlu ditingkatkan.

Tabel 1. Akurasi (\%) pengukuran kurkumin dan BDMC dengan Teknik voltammetri.

Puncak $1 \quad$ Puncak 2

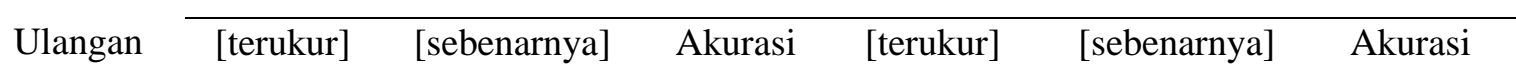

(M)

(M)

(\%)

(M)

(M)

(\%)

\begin{tabular}{crrrrrr}
\hline Kurkumin & & & & & & \\
1 & 0,00096 & 0,00100 & 96,47 & 0,00130 & 0,00100 & 130,41 \\
2 & 0,00110 & 0,00100 & 110,10 & 0,00114 & 0,00100 & 113,53 \\
3 & 0,00087 & 0,00100 & 87,50 & 0,00132 & 0,00100 & 132,16 \\
Rerata & 0,00098 & 0,00100 & $\mathbf{9 7 , 6 9}$ & 0,00125 & 0,00100 & $\mathbf{1 2 5 , 3 6}$ \\
\hline BDMC & & & & & & \\
1 & 0,00110 & 0,00100 & 109,80 & 0,00157 & 0,00100 & 156,61 \\
2 & 0,00086 & 0,00100 & 85,68 & 0,00106 & 0,00100 & 106,16 \\
3 & 0,00098 & 0,00100 & 98,37 & 0,00120 & 0,00100 & 119,85 \\
& 0,0009 & & & & & \\
Rerata & 8 & 0,00100 & $\mathbf{9 7 , 9 5}$ & 0,00128 & 0,00100 & $\mathbf{1 2 7 , 5 4}$ \\
\hline
\end{tabular}




\section{Deteksi Simultan Kurkumin dan Bisdemetoksikurkumin Secara Voltammetri Siklik}

Deteksi simultan kurkumin dan BDMC dilakukan dengan teknik voltammetri pada kondisi pengujian yang telah digunakan pada deteksi kurkumin dan BDMC secara mandiri. Pengukuran dilakukan terhadap larutan sampel yang disiapkan dengan perbandingan 1:1 $\left(5 \times 10^{-3} \mathrm{M}: 5 \times 10^{-3} \mathrm{M}\right)$ dan $7: 1\left(7 \times 10^{-3} \mathrm{M}: 1 \times 10^{-3} \mathrm{M}\right)$. Hasil yang diperoleh disajikan pada Tabel 1. Voltammogram siklik yang diperoleh dari pengukuran larutan campuran kurkumin dan BDMC menunjukkan tiga buah puncak oksidasi pada potensial $+0,3 \mathrm{~V}$ vs $\mathrm{Ag} / \mathrm{AgCl}$ (puncak 1), +1,2 $\mathrm{V}$ atau 1,4 V vs $\mathrm{Ag} / \mathrm{AgCl}$ (puncak 2), dan $+2,0 \mathrm{~V}$ vs $\mathrm{Ag} / \mathrm{AgCl}$ (puncak 3). Berdasarkan potensial puncak oksidasi yang diperoleh, diduga puncak pertama adalah milik kurkumin, puncak pertama mengalami kenaikan intensitas pada saat konsentrasi kurkumin dinaikkan dari $5 \times 10^{-3} \mathrm{M}$ (pada perbandingan $1: 1$ ) menjadi $7 \times 10^{-3} \mathrm{M}$ (pada perbandingan 7:1). Puncak kedua diduga merupakan puncak 1 BDMC yang mengalami pergeseran ke potensial lebih positif sebagai indikasi lebih sulit mengalami oksidasi saat berada bersama kurkumin, puncak BDMC ini diduga bertumpang tindih dengan puncak 2 kurkumin. Intensitas puncak ini mengalami kenaikan saat konsentrasi kurkumin meningkat, yaitu pada perbandingan 7:1. Puncak ketiga diduga merupakan puncak 2 BDMC, intensitas puncak ini mengalami penurunan saat konsentrasi BDMC turun, yaitu pada perbandingan 7:1 (Gambar 5).

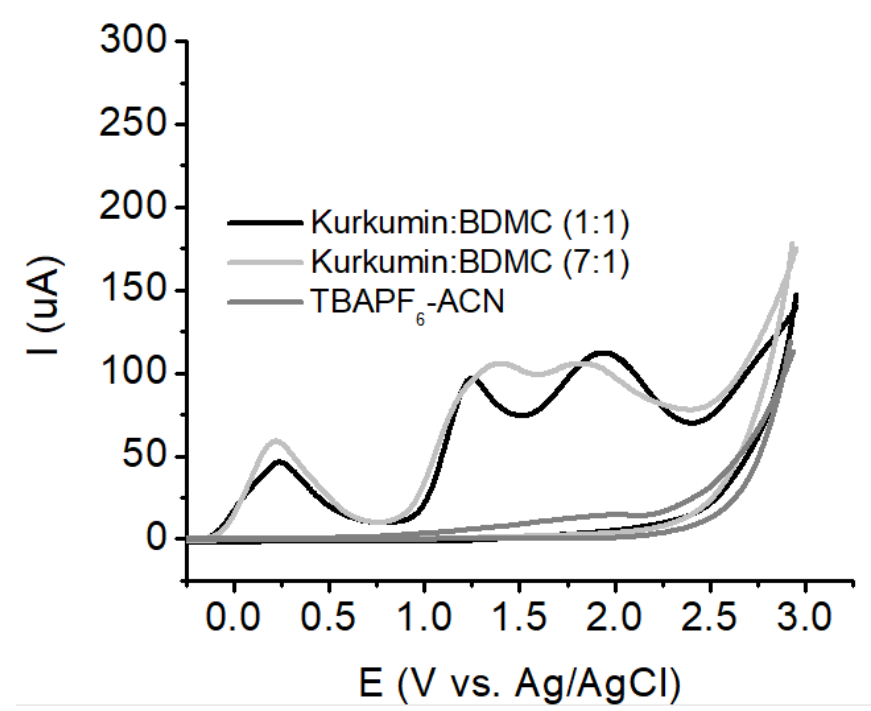

Gambar 5. Voltammogram siklik campuran kurkumin dan BDMC dalam TBAPF 6 -ACN $0.01 \mathrm{M}$.

Analisis kuantitatif kurkumin dilakukan berdasarkan puncak pertama. Intensitas arus oksidasi puncak pertama digunakan untuk menghitung konsentrasi kurkumin berdasarkan kurva kalibrasi standar kurkumin. Diperoleh konsentrasi kurkumin sebesar 4,8 
mM pada sampel campuran kurkumin : BDMC dengan perbandingan 1:1. Sementara itu, pada sampel kurkumin : BDMC 7:1 diperoleh kadar kurkumin sebesar 6,2 mM (Tabel 2). Berdasarkan hasil tersebut dapat disimpulkan bahwa metode voltammetri siklik dapat digunakan untuk mendeteksi simultan kurkumin dan bisdemetoksikurkumin walaupun pada pengukuran kuantitatif, akurasi pengukuran masih perlu ditingkatkan.

Tabel 2. Kadar kurkumin sampel buatan.

\begin{tabular}{ccccc}
\hline Perbandingan & $\mathbf{I}(\boldsymbol{\mu A})$ & $\begin{array}{c}\text { Konsentrasi } \\
\text { Kurkumin } \\
\text { Standar (M) }\end{array}$ & $\begin{array}{c}\text { Konsentrasi } \\
\text { Kurkumin } \\
\text { Terukur (M) }\end{array}$ & Akurasi \\
\hline $1: 1$ & 42,0490 & 0,0050 & 0,0048 & $96 \%$ \\
$7: 1$ & 54,3600 & 0,0070 & 0,0062 & $88,6 \%$ \\
\hline
\end{tabular}

\section{KESIMPULAN}

Pengukuran simultan kurkumin dan bisdemetoksikurkumin (BDMC) dengan teknik voltammetri telah berhasil dilakukan dalam elektrolit tetrabutilamonium heksafluorofosfat $\left(\mathrm{TBAPF}_{6}\right)$ dalam asetonitril 0,01 $\mathrm{M}$ pada elektrode boron-doped diamond. Pengukuran kurkumin dan BDMC masing-masing menunjukkan dua puncak oksidasi. Secara umum puncak pertama kurkumin $(+0,4 \mathrm{~V}$ vs $\mathrm{Ag} / \mathrm{AgCl})$ muncul pada potensial yang lebih rendah dibandingkan puncak oskidasi BDMC (+0,6 V vs $\mathrm{Ag} / \mathrm{AgCl})$. Puncak kedua muncul pada potensial yang hampir sama yaitu $+1,8 \mathrm{~V}$ dan $+1,9 \mathrm{~V}$ vs $\mathrm{Ag} / \mathrm{AgCl}$ untuk kurkumin dan BDMC. Pengukuran kurkumin dan BDMC secara simultan menunjukkan tiga puncak oksidasi, puncak pertama diduga milik kurkumin, puncak kedua kedua diduga merupakan puncak oksidasi 1 BDMC yang mengalami pergeseran ke potensial lebih positif sebagai bertumpang tindih dengan puncak oksidasi 2 kurkumin, sementara puncak ketiga diduga puncak oksidasi 2 BDMC. Unjuk kerja metode meliputi parameter presisi dan akurasi belum cukup memuaskan sehingga metode yang dikembangkan masih perlu dioptimumkan sebelum diaplikasikan untuk analisis kuantitatif.

\section{UCAPAN TERIMA KASIH}

Ucapan terima kasih disampaikan kepada Prof. Yasuaki Einaga, Keio University, Jepang untuk support fasilitas pembuatan elektrode boron doped diamond. Penulis menyatakan bahwa tidak ada konflik kepentingan dengan pihak-pihak yang terkait dalam penelitian ini. 


\section{DAFTAR PUSTAKA}

Bandzuchova, L., Svorc, L., Sochr, J., Svitkova, J., Chylkova, J., 2013. Voltammetric Method for Sensitive Determination of Herbicide Picloram in Environmental and Biological Samples Using Boron-doped Diamond Film Electrode. Electrochimica Acta 111, 242-249. doi: 10.1016/j.electacta.2013.08.071.

Bansal, S.S., Goel, M., Aqil, F., Vadhanam, M.V., Gupta, R.C., 2011. Advanced Drug Delivery Systems of Curcumin for Cancer Chemoprevention. Cancer Prevention Research (Phila) 4, 1158-1171. doi: 10.1158/1940-6207.

Bliesner, D.M., 2006. Validating Chromatographic Method: A Practical Guide. New Jersey: John Wiley \& Sons.

Chan CC, Lee YC, XueMing Z., 2004. Analytical Method Validation and Instrument Performance Verification. New Jersey (US): John Wiley \& Sons.

Çikrikci, S., Mozioglu, E., and Yilmaz, H., 2008. Biological Activity of Curcuminoids Isolated from Curcuma longa. Record of Natural Products 2(1), 19-24.

Fujishima, A., Einaga, Y., Rao, T.N., and Tryk, D., 2005. Diomand Electrochemistry, first ed. BKC-Elsevier. Tokyo.

Gordon, O., 2014. Oxidative Transformation of Curcumin: Product and Reactions Mechanism. Disertasi. Vanderbilt University.

Himesh, S., Sharan, P.S., Mishra, K., Govind, N., Singhai, A.K., 2011. Qualitative and quantitative profile of curcumin from ethanolic extract of Curcuma longa. International Research Journal of Pharmacy 2(4), 180-184.

Ivandini, T.A., Kensuke, H., Tata, N.R., Akira, F., and Yasuaki, E., 2007. Simultaneous Detection of Purine and Pyrimidine at Highly Boron-doped Diamond Electrodes by Using Liquid Chromatography. Talanta 71(2), 648-655. doi: 10.1016/j.talanta.2006.05.009.

Lawhavinit, O., Kongkathip, N., and Kongkathip, B., 2010. Antimicrobial Activity of Curcuminoids from Curcuma longa 1. on Pathogenic Bacteria of Shrimp and Chicken. Kasetsart Journal (Natural Science) 44, 364-371.

Li, K., Li, Y., Yang, L., Wang, L., Ye, B., 2014. The Electrochemical Characterization of Curcumin and Its Selective Detection in Curcuma Using a Graphene-Modified Electrode. Analytical Methods 6(19), 7801-7808. doi: 10.1039/C4AY01492H.

Long, Y., Wenpheng, Z., Fang, W., Zilin, C., 2014. Simultaneous Determination of Three Curcuminoids in Curcuma longa L. By High Performance Liquid Chromatography Coupled with Electrochemical Detection. Journal of Pharmaceutical Analysis 4(5), 325-330. doi: 10.1016/j.jpha.2013.10.002.

Lungu, A., Ileana, S., Cristian, B., Stefan, T., and Constantin, M., 2010. Electrochemical Study of Curcumin and Bisdemetoxycurcumin on Activated Glassy Carbon Electrode. Revue Roumaine de Chimie 55(2), 109-115.

Manaia, M.A.N., Diculescu, V.C., Gil, E., Oliverira-Brett, A.M., 2012. Guaicolic Spices Curcumin and Capsaicin Electrochemical Oxidation Behaviour at a Glassy Carbon Electrode. Journal of Electroanalytical Chemistry 628, 83-89. doi: 10.1016/j.jelechem.2012.06.023 
Moorthi, C. and Kathiresan, K., 2013. Reversed Phase High Performance Liquid Chromatographic Method for Simultaneous Estimation of Curcumin and Quercetin in Pharmaceutical Nanoformulation. International Journal of Pharmacy and Pharmaceutical Science 5, 622-625.

Mosovska, S., Petakova, P., Kalinak, M., and Mikulajova, A., 2016. Antioxidant Properties of Curcuminoids Isolated from Curcuma longa L. Acta Chimica Slovaca, 9(2), 130135. doi: 10.1515/acs-2016-0022.

Nagappan, K.V., Meyyanathan, S.N., Raja, R.B., and Kannan, E., 2009. A Liquid Chromatography Method for the Simultaneous Determination of Curcumin and Piperine in Food Products Using Diode Array Detection. Asian Journal of Research in Chemistry 2(2), 115-118.

Ranjith, A., Menon, K.R., Roshny, S., Gunjan, P., 2016. UPLC-PDA Estimation of Curcuminoids as Marker Compounds for Curcuma longa L. in Spice Mixtures and Herbal Formulations. Quality Assurance and Safety of Crops \& Foods 9(2), 201206. doi: 10.3920/QAS2015.0848.

Svorc, L., Tomčik, P., Svitková, J., and Bustin, D.,. 2012. Voltammetric Determination of Caffein in Beverage Samples on Bare Boron-Doped Diamond Electrode. Food Chemistry 135, 1198-1204. doi: 10.1016/j.foodchem.2012.05.052.

Švorc, L., Cinková, K., Samphao, A., Stankovíć, D.M., Mehmeti, E., and Kalcher, K., 2015. Voltammetric Determination of Harmaline in Natural Food Products Using Boron Doped Diamond Electrode. Journal of Electroanalytical Chemistry 744, 37 44. doi: 10.1016/j.jelechem.2012.03.004.

Vanysek, P., Luis, B.R., 2008. Interface between two immicible liquid electrolytes: a review. Journal of the Chilean Chemical Society 53 (2), 1455-1463. doi: 10.4067/S0717-97072008000200002.

Wang, J., 2006. Analytical Electrochemistry Third Edition. New York (US): Willey.

Zhang, D., Ouyang, X., Ma, J., Li, L., and Zhang, Y., 2016. Electrochemical Behavior and Voltammetric Determination of Curcumin at Electrochemically Reduced Graphene Oxide Modified Glassy Carbon Electrode. Electroanalysis 28, 749-756. doi: 10.1002/elan.201500494.

Ziyatdinova, G.K., Nizamova, A.M., and Budnikov, H.C., 2012. Voltammetric Determination of Curcumin in Spices. Journal of Analytical Chemistry 6(6), 591594. doi: 10.1134/S1061934812040132. 